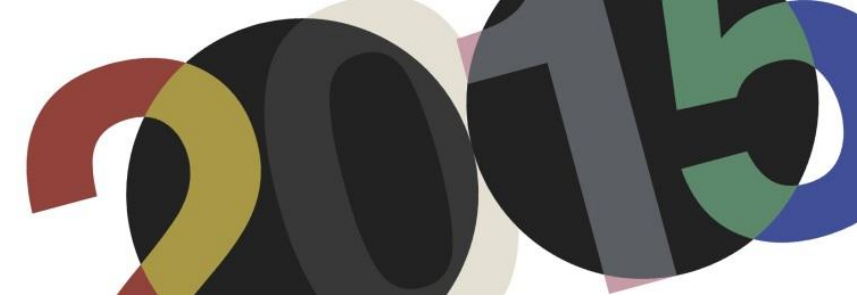

DOI: http://dx.doi.org/10.4995/LC2015.2015.918

\title{
Le Corbusier and The Americas: Affinities, Appropriations and Anthropophagy
}

\author{
D. Ortiz dos Santos
}

Swiss Federal Institute of Technology ETH Zurich

\begin{abstract}
The paper draws attention to Le Corbusier's first trip to the American continent, with a particular focus on his visions and expectations built before the corporeal dislocation to the New World in September 1929. This approach suggests not only an investigation of one single voyage, but of multiple ones, and above all intellectual ones. Voyages that cross biographies, discourses and practices - in a public and intimate scale - which are attentive to a history embodied in its social actors allowing a confrontation of materials that transcends the so called architectural field. It examines one critical moment of ruptures in Le Corbusier's production (1925-1930), and works across the architectural discussions at that time, placing Le Corbusier in a wider web of reciprocal influences and circulation of ideas in order to help to construct a sense of the fragmented, or even silenced, discourses within the artistic and architectural debates in the late twenties. Such an approach not only allows new interpretations but also the establishment of a new periodization on Le Corbusier's knowledge of- and interests in- the Americas, as well as the narratives produced.
\end{abstract}

Resumen: El artículo llama la atención sobre el primer viaje de Le Corbusier al continente americano, con un foco particular en las visiones del arquitecto y sus expectativas construidas antes del 'desplazamiento corpóreo' al nuevo mundo en septiembre de 1929. Desde esta perspectiva, proponemos investigar no sólo un viaje, sino múltiples viajes, y sobre todo los 'viajes mentales'. En otras palabras, examinamos viajes que cruzan biografías, discursos y prácticas, en una escala privada y también pública. Atentos a una historia encarnada en los actores sociales, nos permitimos una confrontación de documentos que extienden el campo de la arquitectura. Analizamos así un momento crítico y de rupturas en la producción de Le Corbusier (1925-1930), situándolo en una amplia red de sociabilidad y debates en los últimos años de la década de 1920, cuyas influencias, afinidades y circulación de ideas se entrelazan. Al trabajar con este abordaje, posibilitamos nuevas interpretaciones y también el establecimiento de una nueva periodización de Le Corbusier y su relación con las Américas.

Keywords: Le Corbusier; Travel; The Americas; Brazil; Blaise Cendrars; Lucien Romier.

Palabras clave: Le Corbusier; Viaje; Las Américas; Brasil; Blaise Cendrars; Lucien Romier.

\section{Introduction ${ }^{1}$}

"Mon cher Giedion, Rentré d'Amérique.(...) pendant tout mon voyage, où j'ai vécu intensément les problèmes d'urbanisme" Le Corbusier, 10 January $1930^{2}$

The choice of naming the most vivid chapter of Précisions (1930) as Prologue Américain, or even Le Corbusier's use of the term 'Amérique' to inform Giedion of his return from Brazil and Argentina seems to be no longer meaningless coincidence, but again critical evidence of Le Corbusier's visions and strategies regarding the new world. By accentuating nuances and complexities in Le Corbusier's networking between 1925-1930, this paper argues that Le Corbusier's construction of the notion of America not only seems to go far beyond the sphere of the United States, but also proves to be changeable and very much influenced by individuals with

\footnotetext{
${ }^{1}$ This paper is based on my doctoral studies in progress at the Institute for the History and Theory of Architecture at ETH Zurich, with support from the Swiss National Science Foundation

${ }^{2}$ Letter from Le Corbusier (LC) to Giedion (SG), 10 Janurary 1930, gta/ETH archives
} 
whom he shared admiration and affinity. I draw attention to Le Corbusier's first trip to the American continent, with a particular focus on his visions and expectations built before the corporeal dislocation to the New World. While the official voyage would originate in Bordeaux on the cruiser Massilia heading for Brazil, Uruguay and Argentina in September 1929, his 'real journey' began long before this transatlantic crossing. This approach suggests then not only an investigation of one voyage, but of multiple ones, and above all intellectual ones. Voyages that crosses biographies, discourses and practices - in a public and intimate scale - that which is attentive to a history embodied in its social actors allowing for a confrontation of materials that transcend the so called architectural field.

The twenties in particular proved to be years of intense circulation among various groups of artists, academics and politicians in France, in Europe and overseas, Brazil included. Le Corbusier's visions of the Americas seem to be deeply affected by these social and intellectual constellations, consequently contributing to reshape his interests and political agenda. Analysis that reassesses the role of some individuals within Le Corbusier's social network in the architect's own practices turn out to be no longer incidental but critical for the studies on Le Corbusier and the new world. This paper examines one critical moment of ruptures in Le Corbusier's production (1925-1930), and works across the architectural discussions at that time, placing Le Corbusier in a wider web of reciprocal influences and circulation of ideas and as so help to construct a sense of the fragmented, or even silenced, discourses within the artistic and architectural debates in the late twenties.

Instead of linking Le Corbusier's discourse on the Americas with major conceptual movements, such as Taylorism or Fordism -already exhaustively explored by a number of scholars and that essentially focused on the 'US sphere ${ }^{3}$-, I would suggest a more blurred field in which affinities, affections and appropriations, which are fluid and embrace other geographies too, would play a capital role in Le Corbusier's practices and discourse at this time. Such an approach not only allows new interpretations but also the establishment of a new periodization on Le Corbusier's knowledge of- and interests in- the Americas, as well as the narratives produced. As I will show, the second half of the twenties is particularly marked by the introduction of the Southern part of the American continent into Le Corbusier's discourse on America.

\section{Strategies redesigned through America: Impacts of New Alliances on Le Corbusier's Discourse}

"Mon cher Giedion, Nous, les représentants de toute l'Europe technique, nous voyons clair. Nous affirmons, nous réclamons, nous demandons, au nom de l'architecture. Nos voix ont le poids du monde professionnel, etc.(...) Je pourrais d'autre part, vous donner les noms de hautes personnalités enthousiastes, telles que Mal Lyautey, Voisin, Cendrars, Romier etc etc. et les articles déjà parus. Et qu'ainsi nous recommencions, cette foisci d'ensemble, sur un document bien établi, complet, sur lequel s'appuieraient les associations. ” Le Corbusier, 30 December $1928^{4}$

\footnotetext{
${ }^{3}$ The most significant contributions on this issue have been made by McLeod, Passanti, Bacon, and recently Leitner, resulted from their doctoral studies. The seminar and publication on Americanism and Modernity organized by Damisch and Cohen also brings togheter luminous esssays on Le Corbusier's visions of the Americas, focusing on the US sphere. See: McLeod, M. Urbanism and Utopia: Le Corbusier from regional syndicalism to Vichy; Passanti, F. "Des gratte-ciel pour la 'ville contemporaine"”, pp.54-65; Bacon, M.: Le Corbusier in America. Travels in the Land of the Timid; Leitner, P. Entre Paris et New York. Dynamiques d'échange pour transformer la métropole 1858-1926

${ }^{4}$ Letter from LC to SG, 30 December 1928, gta/ETH archives
} 
1920-1928: Those would be years of a great amount of 'militant statements' produced by Le Corbusier, in which the use of plural first person pronouns is vastly explored: "Nous affirmons, nous réclamons, nous demandons", he claims in the "name of architecture". His publications and conferences from the twenties have indeed been subject of uncountable studies by scholars. ${ }^{5}$ There is, however, another fragment of Le Corbusier's words of 1928 that appears to be ignored so far. In particular, the list of names of "highly enthusiastic personalities", to borrow Le Corbusier's terms, "representatives of all of technical Europe", who together with Le Corbusier as he describes, also see the paths to be taken "bright and clear". In times of the formation of a group meeting to discuss further directions of the modern architecture, Le Corbusier does not hesitate to relate names of notable figures to Gideon that could support and legitimate the meeting. Voisin, Lyautey, Romier, Cendrars: these are names that despite having been apparently chosen at random by Le Corbusier, deserve some attention.

What could an automobile entrepreneur, a high-ranking military Marshal, an editor of French Newspaper Le Figaro, and a poet have in common in order to have their names pointed out by Le Corbusier? ${ }^{6}$ Why invite such names to join the debates and not others already established within the architectural field? Although these questions may seem straightforward at first glance, answering them poses considerable analysis and demands. As I will shortly show in the following, these four names produced extraordinary work at this time, therefore critically affecting their own 'fields of action'. Further, their practices would echo -in different degrees- complex operations of the French discourse towards the geo-political and economic changes in the first quarter of the twentieth century, relations with the overseas in particular. Le Corbusier's visions of the new world appear to be thus more complex and blurred than those that have been discussed so far.

My intention is not to develop a linear interpretation by proposing such interrogations, but rather to accentuate nuances and complexities in Le Corbusier's networking in the late twenties and how the construction of the notion of the new world is meandering and heterogeneous, transcending the North American discourse too, which has so far prevailed in historiography. ${ }^{7}$

\footnotetext{
${ }^{5}$ Lucan, Benton, Von Moos, Passanti, Cohen among others, whose critical approach to Le Corbusier is based on the architects' files for at least three decades, have strongly contributed to unfold Le Corbusier's discourse, and are therefore names to single out. Amongst their most relevant work: Lucan, J. (Ed.): Le Corbusier: Une Encyclopédie; Benton. T.: Le Corbusier conférencier; von Moos, S.: Le Corbusier: Elements of a synthesis; von Moos, S.: "Urbanism and Transcultural exchanges, 1910-1935: A Survey”, pp. 219-232; von Moos, S.: Le Corbusier und die Industrie, 1920-1925; Von Moos, S., Rüegg, A. (Ed.): Le Corbusier Before Le Corbusier; Passanti, F.: "Des gratte-ciel pour la "ville contemporaine"”, pp.54-65; Passanti, F.: "Le Corbusier et le gratte-ciel, aux origines du Plan Voisin”, pp.171-190; Passanti, F.: "The Vernacular, Modernism and Le Corbusier", pp.438-451; Cohen, J-L.: Le Corbusier et la mystique de l'URSS. Théories et projets pour Moscou 1928-1936; Cohen, J-L.: Le Corbusier : La planète comme chantier, Paris : Textuel, 2005; Cohen, J-L. (Ed.): Le Corbusier: An Atlas of Modern Landscapes

${ }^{6}$ Pilot and businessman Gabriel Voisin (1880-1973), whose work and ideas had a great impact on Le Corbusier's discourse in early twenties; M ${ }^{\mathrm{al}}$ Lyautey (1854-1934), a former minister of War in France but whose intervention in Morocco and interests in urbanism were familiar to Le Corbusier; Lucien Romier (1885-1944), medieval historian trained at Ecole Nationale de Chartres who became an influential voice on socio-economic affairs policy making in France towards the booming US in the twenties; and poet Blaise Cendrars (1887-1961), a known figure in the French literary world, already very close to artists familiar to Le Corbusier as Sonia Delaunay and Fernand Léger

${ }^{7}$ In Damisch and Cohen's preface to the conference and, later, the book Américanisme et Modernité, the notion of modernity cannot be detached from the idea of the 'New World'. Both call attention to the fact that such processes, very much evident in the twentieth century, are a part of a long historical product wherein varying symbolic and complex features are involved. Despite the attention given to the case of the United States of America, some of their arguments and historical approach may be extended to the context of the whole American Continent. In fact, scholars such as Margareth da Silva Pereira have already called attention to this approach. She insists that the concept of Americanism shall not exclusively encompass the 'North American Sphere' - as presented by Damisch and Cohen. The section dedicated to examine Le Corbusier's and the
} 
By dedicating a few words to these figures mentioned in Le Corbusier's correspondence, I attempt to challenge Le Corbusier's view of the Americas before 1930, and claim that his discourse is much more deeply affected by individuals from his social network than by the commonplace discourse produced in the US and France. I am to demonstrate that the inclusion of Cendrars into such a list sent to Giedion isn't a mere coincidence, but rather a critical evidence of Le Corbusier's visions and strategies towards the new world.

\section{American Utopia associated with the Prosperous US Industry Model: Le Corbusier's encounter with Gabriel Voisin}

Although Reyner Banham in his review on Stanislaus von Moos' publication Avant Garde und Industrie credits the Swiss historian for revealing the association of Le Corbusier to his "notorious patron of the mid-1920s, the ebullient and eccentric industrialist Gabriel Voisin (1880-1973)", 8 such a connection has never been obscured by Le Corbusier himself, precisely after the exhibition of Le Corbusier's urban plan for Paris in 1925 at the exposition internationale des Arts Décoratifs et Industriels modernes, entitled with the industrialist's name. Not to mention the use of car Voisin $14 \mathrm{CV}$ - also owned by Le Corbusier himself, probably received as part of his retribution - to be displayed together with the architect's housing projects in several photos, later published in magazines and Le Corbusier's own books at this same decade. Both cases, including the construction of the Esprit Nouveau Pavilion in 1925 with the sponsorship of Voisin and other industrialist, Henry Frugès, have indeed been subject of studies by Francesco Passanti and his student M. Shaw yet simultaneously Von Moos discloses the peculiar relationship between Voisin and Le Corbusier. ${ }^{9}$ What Von Moos enlightens however in a consistent argument is that the Kreuzbestäubungen (cross-pollination) between avant-garde and industry in the twenties provokes non-homogeneous yet complex outcomes. By focusing on the case of Le Corbusier and Voisin, Von Moos reveals negotiations but interests too, financially and ideologically. Accordingly, he brings light to both actors' shared poetic understanding in arts and architecture -pointing out Voisin's early architectural studies at the Beaux-Arts school in Lyon- as leitmotifs to explore possible geneses of this short but 'fortuitous' encounter. Mostly through Le Corbusier's work from the twenties -as an architect, writer and chef editor of L'Esprit Nouveau - the interest into Voisin's ventures becomes rather evident. Les maisons 'Voisin' published at the second edition of L'Esprit Nouveau (1920) would mark the beginning of a series of celebrations of the industrialist's affairs. Signed by Le Corbusier-Saugnier, the paper applauds the original solution for building a serial production of houses, in accordance with the 'aesthetics of construction" ('l'esthétique de la construction') of that time since the "art of building" is strongly rooted in science. ${ }^{10}$

\footnotetext{
'Americas', which received contributions of Francesco Passanti, Mardges Bacon and Mary McLeod, are entirely focused on the relation between the architect and the U.S.A.

${ }^{8}$ Banham, R.: Avant Garde und Industrie by Stanislaus von Moos, pp. 277

${ }^{9}$ In the early and mid-1980s scholarship began to problematize the issue of Le Corbusier's attention to the affects and effects of the North-American industrialist production and ideology. Almost parallel to Von Moos' work, Francesco Passanti explores Le Corbusier's plan Voisin and the echoes produced by Taylorism and Fordism in the US onto the architects' projects from the twenties. In addition, Mary McLeod investigates Le Corbusier's engagement with politicians and businessmen, as I will further discuss. As shown by Von Moos, and later investigated in-depth by Marybeth Shaw, Voisin would play a significant role for Le Corbusier's concretization of his ideas, not only sponsoring already mentioned the development of the urban plan for Paris and its exhibition, but also the Esprit Nouveau Pavilion, both from 1925

${ }^{10}$ Le Corbusier-Saugnier: "Les Maisons Voisins". In l'Esprit Nouveau, November 1920, vol.2 p.211. Apud Von Moos, S.: L'Esprit Nouveau. Le Corbusier und die Industrie, 1920-1925, p.169
} 
Despite the presence of Le Corbusier's eulogy to Voisin inferring the use of dissimilar written and visual media, and his prodigious enthusiastic letter encouraging Giedion to contact the industrialist for future CIAM debates; in the private sphere, the exchange between Voisin and Le Corbusier seems to have taken place only decades later. $^{11}$

In fact, Gabriel Voisin's overpowering articulation in building more than ten thousand bomber airplanes for the French Army during the Great War, after 1918 having transformed his factory together with his brother into a prefabricated housing company, ran as an automobile company not long thereafter; allowed him to gain not only an extraordinary notoriety in the business and industrial world but also uncountable sympathizers among the French political and intellectual bourgeois circles, Le Corbusier included. In an almost anecdotic episode, Von Moos highlights the social status the Voisin luxurious car would be associated with in the early twenties and how Le Corbusier appreciated not only having one for private matters, but also using it in his architectural discourse to be addressed to the French bourgeois elite. ${ }^{12}$

Eager to establish his profession as an architect in postwar France and as an urban designer too, Le Corbusier would see in Voisin a promising name in which was associated with three critical matters to the architect at this time: (1) an aesthetic discourse that embraced the engineering technologies, (2) a successful undertaking in the business world translating some of the US booming practices of industry into the French terrain, which (3) enabled concrete results entrenched in the French political agenda. Giedion and Le Corbusier's invitation sent to such successful leader in France to sponsor the upcoming conferences in order to discuss the place of modern architecture and urbanism in contemporary society no longer appears to be mere speculation, but rather a solid plan for a broadened understanding of the role of industrial leaders in the construction of a new socio-political agenda.

"Je pense que nous ne devons surtout jamais devenir un "grand Congrès". Nous devons rester "avantgarde", fermé, restreint, aigü, etc ne pas hésiter à traiter, s'il le faut (et c'est fatal) les mêmes questions que d'autres grands congrès. Mais nous devons donner notre point de vue avant-garde, pur, clair, "idéaliste" même. S'il le faut. Nous ne sommes pas la masse, mais le projecteur." Le Corbusier ${ }^{13}$

In fact, Voisin is not the unique name in the list of figures kept in mind by the organizers of the first meeting. In a letter of 25 July 1928 from Giedion to another automobile industrialist, this time Peugeot director Philipp Girardet, the yet to be secretary of CIAM makes clear that the aims and reasons for the urgency in organizing such a conference, and how industry should be a crucial partner. The goal [of CIAM] was "to replace architecture in its veritable axe, which is economic and sociological". Architecture, Giedion continues, "can be only healed if it works together with industry", whereas "industry needs new architects who know how to codify the secret wishes of our times". He concludes asserting that a "true fruitful development can only take place when architecture and industry commonly collaborate with each other". ${ }^{14}$ It is tempting to make a parallel here with the case of Voisin too; as such discourse on the technological and industrial world seems to be altogether orchestrated by Giedion and Le Corbusier.

\footnotetext{
${ }^{11}$ In Le Corbusier's files, later correspondence of the 1950s revealing words of affection and closeness proved that Le Corbusier and Voisin maintained a mutual admiritation, respect and affinity over many years

${ }^{12}$ Von Moos, S.: "Dans l'antichambre du 'Machine age'”. In Von Moos, S. (Ed.): L'Esprit Nouveau. Le Corbusier und die Industrie, 1920-1925, pp.12-25

${ }^{13}$ Letter from LC to SG, 8 Mai 1929. CIAM Archives, gta/ETH

${ }^{14}$ Letter from SG to Girardet, 25 July 1928, gta/ETH archives
} 
In contrast to the silence of Girardet's name in the final printed version list of Membres du Comité de Patronage of the La Sarraz meeting, other notable French industrialists familiar to Le Corbusier are yet indicated: Henry Frugès, Jean Michelin, and ultimately Gabriel Voisin.

Already in a letter from Gabriel Guevrékian to Karl Moser of 9 June 1928, Voisin's name appears next to an intellectually broad but selective group of names of the French elite who was about to support the meeting, ${ }^{15}$ which include art critics and hommes de lettres as the president of Salon d'Automne Frantz Jourdain; art historian Elie-Faure, who regularly contributed to L'Esprit Nouveau; businessmen such as Le Corbusier's sponsor for dwelling houses in Bordeaux Henry Frugès, Jean Michelin and the head of Crédit du Nord Banking network Administrative Counsel Georges Delebart; engineers as Arthur Fontaine, the president of the International Labour Office; and journalists on politics as Lucien Romier, to whom I will dedicate a few words in a later section.

Although both Giedion and Le Corbusier seem to agree in the capital role of successful industrial production for the legitimation and the establishment of the "new architecture", the construction of their discourses would not share the same references, documents and even methods. At this moment, Giedion's arguments are supported by a critical-historiographic narrative, which claims for the nineteenth-century industrial formation as the genesis of the "new" architecture. For Giedion, such a shift from hand work to industrial production, which affected the contemporary society and architecture too, would take place mainly in European fields and not overseas. Giedion's book Bauen in Frankreich, Bauen in Eisen, Bauen in Eisenbeton, published in $1928,{ }^{16}$ would precisely focus on the French's case ${ }^{17}$ whose introductory words advocate Saint-Simon's concepts of industry and its impacts on urban centers. ${ }^{18}$ As Sokratis Georgiadis indicates, Giedion would devote privileged attention to the images, traveling to Paris in late 1927 with a central purpose of collecting photographic material in the public archives, as well as from the architects' bureau. ${ }^{19}$

In those same years too, Le Corbusier often resorted to particular moments of 'the past' to affirm and support his arguments for modern architecture. Exhaustively he employs graphic and iconographic documentation as part of his discursive strategy. In between texts, Le Corbusier operates a powerful visual appeal: uncountable images of floor plants, cross-sections, isometric drawings and his own sketches of buildings such as the Acropolis in Athens, and Pantheon or the Cathedral of Notre-Dame in Paris; late nineteenth- and early twentieth-century photography of cities or construction sites; and even world city population tables and statistical graphics too. It is a carefully selected iconographic repertoire whose analogy between fragments of the columns of the Parthenon and airplanes would seem not to make sense as a plausibly argument, as demonstrated by Tim Benton. ${ }^{20}$

\footnotetext{
${ }^{15}$ Despite the confirmation of Voisin in supporting the La Sarraz event, absences of Voisin's name in Giedion's archives after 1929 are strong evidences that such encounter between Voisin and the CIAM group haven't progressed. Whether the declination was coming from Voisin or not, so far the surviving material cannot give further acknowledgment, but provide interrogation

16 Originally, the book is a collection of Giedion's articles published in German journal Der Cicerone. For further comprehensive analysis of the production of the book and its context, see Sokratis Georgiadis' introduction of the English vesion of Giedion's Bauen in Frankreich, pp.1-53

${ }^{17}$ In his critical analisys of Bauen in Frankreich, Georgiadis argues that despite choosing France as the field of Giedion's investigation, his "theory had profited mainly from the debate in Germany, which had been going on among architects for eight decades". S. Georgiadis, Introduction of Building in France, Building in Iron, Building in Ferroconcrete by Giedion, p.42

${ }^{18}$ Giedion, S.: Building in France, Building in Iron, Building in Ferroconcrete, pp. 88-89

${ }^{19}$ Ibid, p.45

${ }^{20}$ See: Benton, T.: Le Corbusier conférencier
} 
Unlike Giedion, Le Corbusier, already in his first manifestos on architecture, the most widely known being Vers une Architecture (1923) and Urbanisme (1924), builds a rhetoric which argues that the "new" architecture would have not only its genesis in Europe but also in the American territory. Images and Tables revealing 19th- and 20th industrial production and engineering building of the new continent ${ }^{21}$ place a privileged position in his narratives to rethink architecture in within its present time.

Significantly more interesting to the present proposal is however the modes in which Le Corbusier links past, present and future with America. And, perhaps most critical, is the tenuous but significant narrative that changes between 1928 and 1930, in which the discourse on America is enlarged and sometimes conflicting as well. If the iconographic 'America' of Le Corbusier until 1928 was to a certain extent pending between an eulogy of machinery technologies developed in the precedent century, and an hysteria vis-à-vis the immediate 'cruel' effects of such technologies on people's life (sometimes even announcing a fatalistic attitude towards the future); at the end of the twenties, the European repertoire, which had been so far the main well-founded reference, was gradually giving place to a new inventory of the overseas. America, yet images and texts altogether, turned into a hope and an indication for the future of the inevitable way of living in modern western society, i.e. the city.

In other words, it was a gradual shift from a pure visual appeal of the recent products developed by the advances of science and the engineering of the new world through the 19th and 20th century, to a more poetic, historicaland topographically expanded plastic but also written discourse rooted in new personal experiences and encounters with the new continent. Such encounters, which acted as a potential for Le Corbusier to reconsider a whole new theory on urbanism, began before the transatlantic trip of 1929. But what has been apparently silenced by Le Corbusier is exactly the processes in which such a shift takes place, and how inconsistent and contradictory his practices and discourses became at times. If, on one hand, he criticizes the 'old' and 'dying' Europe in his books, on the other hand, he would stretch alliances with individuals who are precisely claiming for an European 'rebirth', precisely postwar France, on cultural-, economic-, and political levels, as counterpoint to the hegemony coming from the overseas. The cases of Le Corbusier's encounters with French politician Lucien Romier and Swiss-French poet Blaise Cendrars appear to be then exemplary for extending the architect's fluctuating positions and moves in times of an attempt to define and to legitimize modern architecture.

\section{America versus Europe, or France 'on a par with its rivals': Le Corbusier's Ventures between National Politics and International Architecture}

If, on the one hand, there has been certain consensus among scholarship in the necessity to bring light to the relationship between Le Corbusier and industrialist names such as Henry Frugès or even Gabriel Voisin, in order to draw attention to the architect's incorporations of ideas and practices of US industrial utopias as "key to social renewal", ${ }^{22}$ the same cannot be stated with respect to actors from other fields of action, and Marshal Lyautey and journalist Lucien Romier seem to be good examples. For Lyautey, there are only a few texts that establish a link. In this sense, the work of Zeynep Çelik and Jean-Pierre Frey introduces a coherent narrative in exploring both Lyautey and Le Corbusier's relations to North Africa through Said's approach on Orientalism. But what about Lyautey's practices as an urbanist? Why would Le Corbusier correlate him to Giedion on the subject of CIAM?

\footnotetext{
${ }^{21}$ Firstly naming only by country as USA, Canada, Panama in the first volume of the Collection de L'Esprit Nouveau from 1923, but soon afterwards by cities too, like Chicago and New York appearing in Urbanisme in 1924, or Buenos Aires and Rio de Janeiro in Précisions, the last volume of the Collection de L'Esprit Nouveau (EN)

${ }^{22}$ I borrow these words from McLeod who assessed Le Corbusier's understanding of Taylorism. See: McLeod, M. Urbanism and Utopia: Le Corbusier from regional syndicalism to Vichy, p.40
} 
While struggling in France amongst French politicians and the intellectual elite in order to operate within the governmental apparatus and to build, Le Corbusier would claim for international debates and contacts to be held in parallel in order to establish and to legitimize a basis for the modern architecture, in France and abroad. In this sense, the architect seems to be very much aware of the benefits of intersecting the numerous fields and webs of people where he circulates.

"Depuis mon départ de Corseaux, l'affaire PdN suit une marche hors de sentiers de la colère. [...] Mais moi, j'ai tenté de faire autre chose, en jouant sur terrain sûr. Et il se peut que cela n'aille pas mal. Il se peut que maréchal Lyautey (fort épris de mes initiatives) accepte d'être en tête du mouvement." Le Corbusier ${ }^{23}$

After the refusal of his project for the Palais des Nations (PdN) in Geneva, Le Corbusier indicates to his mother that he would hence "play on safe ground", suggesting thus the prominent exchange with seventy-year old Hubert Lyautey, yet Marshal and Commissioner-General of the International Colonial Exhibition that would take place in Paris 1931. Hurbert Lyautey (1854-1934), who being a central name in the first quarter of the 20th century decision making on future developments of French colonies in North Africa, has certainly not escaped the attention of Le Corbusier. Despite being drafted during the trip to Morocco in 1931 together with Pierre Jeanneret and Fernand Léger, Le Corbusier's sketchbook B7 serves as good evidence here. With divagating notes and open analysis on Lyautey's operations in this territory under the French control, Le Corbusier calls up for a "Destin de l'Occident!" (Destiny of the West!) ${ }^{24}$ to create an argument for an inevitable approach towards modernity. ${ }^{25}$

"The destiny of the West", he insists, that is to "act, compose, [and to] create modern life". ${ }^{26}$ What is interesting to us here appears to be the just following sentence, which not only indicates Le Corbusier's awareness of different ways of "creating modern life" but the refusal of models undertook by the Germans and Americans of the United States. ${ }^{27}$ As Paul Rabinow argues, "there was a chance, Lyautey and others believed" -here we could insert Le Corbusier as one of those names- "that through the creation of new social techniques, France could successfully enter the modern world on a par with its rivals". ${ }^{28}$ Le Corbusier's attention to Lyautey has been called while the latter served as Governor-general of Morocco (1912-1925), already addressed in previous paragraphs, but most particularly as a participant of Le Redressement Français, a movement strengthened in late twenties, whose aims were to bring together the industrial and private business elite in order to actively take the leadership in the social-political agenda of the country. ${ }^{29}$ Founded in 1925 by the future head of the French Oil

\footnotetext{
${ }^{23}$ Letter from LC to his mother. January 20 1928, FLC

${ }^{24}$ Le Corbusier carnet B7 (FLC Archives). Apud Franclieu, F.: Le Corbusier Sketchbooks, pp. 436-440

${ }^{25}$ According to De Franclieu and several other scholars, Le Corbusier's notes were as useful memory aid for texts published late 1931 and 1932 in monthly Magazine Plans, whose chief editor was Philippe Lamour. See: Franclieu, F.: Le Corbusier Sketchbooks

${ }^{26}$ Ibid, pp. 437-438

${ }^{27}$ It is indeed very ambiguous Le Corbusier's use of the term 'Americans' in his private and published texts until mid-thirties. Thus a direct link between the term and an assumed meaning calls for caution when looking over his discourse. For this specific case, in which Le Corbusier compares France's socio-, politic- and economic situation in dealing with the global crisis after 1929 with other States that had experience a booming economy too, I assume that he addressed to the cases of Germany and the US only. In fact, Le Corbusier's article "Spectacle de la vie moderne" published in Plans in March 1932 (FLC) embodies precisely these issues and comparisons, however, instead of 'America' Le Corbusier clearly writes 'U.S.A.'

${ }^{28}$ Rabinow, P.: French Modern. Norms and Forms of the Social Environment, p.106

${ }^{29}$ In his studies on Ernest Mercier, Richard F. Kuisel articulates the role of the Redressement in the decisions of French politics in 1928. One example was the money invested by Mercier's organization to fund the election of several French politicians. Kuisel continues, "the Redressement also assumed the task of studying all social and economic measures
} 
Company Ernest Mercier (1878-1955), a name that was included in Le Corbusier's list of personalities he would be 'in contact with' when writing to his mother. ${ }^{30}$

"Au Redressement Français le patron Mercier, est venu exprès pour me dire tout ce qu'il pensait de mon rapport: "Je désirais voir l'homme qui a fait ce rapport". Je déjeunerai ces jours-ci avec le maréchal Lyautey." Le Corbusier ${ }^{31}$

Despite the absence of any concrete action on his part within the CIAM, Lyautey, as representative of the Redressement, is indeed mentioned in one of the very first protocols built just after the meeting of the CIAM delegates that took place in Basel in February of 1929. In between uncountable documents produced after that meeting, this revealing protocol brings light to the heated debates of the encounter in Basel with accuracy, issues which were mainly focused on the content and the format of the second CIAM congress to be held in Frankfurt. For the third day of the program - clearly stated as the most conflictual one amongst the delegates, the question of property and finance is defined to be addressed, and amongst proposed invited speakers, Lyautey. ${ }^{32}$ But more significant than an indication of the appearance of the Marshal's name in the CIAM files, is perhaps arguably the regularity of other names from the Redressement in the documents produced in late twenties by this group, which was in the process of institutionalizing a new agenda for Architecture. ${ }^{33}$

One intriguing protagonist, with whom Le Corbusier would have strengthened his contacts and exchanges with in 1928 and 1929, and who, via the architect's influence, would end up becoming an official member of CIAM's comité de Patronage, is Lucien Romier (1885-1944). The historian and former editor of Le Figaro, having an active voice at the Redressement, insisted that Mercier's organization "had long maintained that housing was the

considered by the legislature in order to advise both its members and the lawmakers. It maintained close contact with a small number of party leaders who sympathized with its views". Kuiser, F.: Ernest Mercier: French Technocrat, Berkeley - Los Angeles: University of California Press, p.85. For further reading on Le Corbusier's engagement with Redressement see: M. McLeod, M.: "Architecture or Revolution: Taylorism, Technocracy, and Social Change", pp.132-147

${ }^{30}$ Le Redressement also counted on the support of more familiar figures to Le Corbusier such as engineer Louis Loucheur (1872-1931), who being Minister of Labor and Social Welfare encouraged the construction of low-cost housing (Habitations à bon marché). The housing law of 1928 would be a theme of great interest for Le Corbusier, who would have not only published a few texts on this issue in the late twenties, but also aroused debates and attention to his peers in France and abroad. Giedion would be one of Le Corbusier's peers, who was interested in writing on the issue of the Loi Loucheur. The secretary of CIAM would address this theme in the article Weissenhofsiedlung und Paris published in the Stuttgart Journal Werkbund Gedanken. Für Volksbildung, Kunsthandwerk und Industrie, on 20 October 1928. Fragments of the article can be found in an un-published text dated from 18 September 1928, which is addressed to the director of the Journal Lumière under the title La Loi Loucheur et une exposition d'habitation (gta/ETH Archives). I am grateful for Andreas Kapakci for calling my attention of these documents

31 Letter from LC to his mother, January 20, 1928, FLC. Apud Baudouï, R., and Dercelles. A.: Le Corbusier. Correspondance. Lettres à la famille 1926-1946, p. 106

${ }^{32}$ Lyautey is suggested by Le Corbusier to speak about the documentation and stance of the Redressement on recovery of interest and capital gains, and land consolidation. Tim Benton's analysis of Le Corbusier, social housing, Loi Loucheur and the architect's attempts to participate in numerous circles of the French elite involved in this issue shall be singled out here. Benton draws attention to the echoes that Lyautey's terms and decrees in Morocco produced in Le Corbusier's discourse on housing and the divisions of land. In this sense, Benton may be referring to Le Corbusier's talk on the third meeting of CIAM, in which precisely the architect links the success of a modern urbanisation to the necessity of the land repartition. See: Le Corbusier : "Le parcellement du sol des villes", pp.48-57; Benton, T. "La réponse de Le Corbusier à la loi Loucheur", pp. 238-239

${ }^{33}$ This protocol built after the meeting in Basel February 1929, where the name of Lyautey is listed, indeed mentioned other two protagonists from the Redressement: Lucien Romier and the director of Comité des Forges, namely the founder of Redressement Ernst Mercier. Source gta/ETH Archives 
principal problem of the working class in Paris". ${ }^{34}$ Mostly known as the Minister of Petain during WWII, Romier would be an active writer in the late twenties on the question of urban agglomeration and economy in several influential newspapers in France, ${ }^{35}$ and would be present in numerous political organizations and circles such as the National Committee of French Foreign Trade Advisors. ${ }^{36}$

Although apparently discreet amongst the several names and issues raised by Le Corbusier and Giedion between 1928 and 1929, the one concerning Romier is consistently present in their correspondence. Le Corbusier appears to be convinced of bringing the speaker of the Redressement into the CIAM meetings, and the strongest evidence is found in the numerous protocols as well, minutes and reports prepared for the second CIAM congress to be held in September 1929. Later versions of the program shows that it's no longer Lyautey but Romier altogether with Martin Wagner from Berlin who would hold a session on the third day of the congress in Frankfurt. The session, which persisted to focus on the remembrement des sols, ${ }^{37}$ would later disappear from the final version of the program, and the last day of the conference ended up to be dedicated to discussion.

Mary McLeod was pioneer in bringing light to Le Corbusier's professional contacts with Romier. That the speaker of Redressement shall be invited to become a patron of CIAM is given in Le Corbusier's mediation. Nonetheless, the architect's private files show not only that a great admiration and empathy were built between Le Corbusier and Romier, but also an exchange that involved issues of private matters too. His agenda and correspondence with family reveal indeed a relationship, which went beyond professional contacts, such as Romier's encouragement for Le Corbusier to gain French citizenship. In a letter to his mother from November 1928, the architect indicates that once "le cas nationalité (the nationality issue) is solved" - here Le Corbusier's words are clearly associated with concrete plans to marry his French girlfriend Yvonne - the chances for commissioned works in France could advance. ${ }^{38}$

“J'en arrive maintenant à devoir prendre aussi une nouvelle grande décision préálable. J'ai bien réfléchi, depuis des années. Voici: Je vis dans un pays où j'apporte mes idées mais dont aussi je tire toute ma sève. Je suis consideré comme étant à la tête de l'architecture française. Il y a dans le fond équivoque: vous êtes suisse, me dit-on. (...) J'ai causé de cela à Romier. Il estime que je dois me rattacher à la France. Je n'ai jamais eu le sens des frontières. (...) pour réaliser mes intentions avec Yvonne, je veux d'abord liquider le cas nationalité. Dis-moi ce que tu en penses. " Le Corbusier ${ }^{39}$

\footnotetext{
${ }^{34}$ Kuiser, F.: Ernest Mercier: French Technocrat, p. 86

${ }^{35}$ Besides writing for Le Figaro from 1925 until 1927, Romier's texts on France, the US economy would also appear in the monthly magazine Revue des deux mondes between 1927 and 1930. See digital archives of Revue des deux mondes: <http://www.revuedesdeuxmondes.fr/archive/search.php?section\%5B\%5D=ARTICLE\&author=LUCIEN+ROMIER>

${ }^{36}$ In Un milieu libéral et européen, Laurence Badel indicates that Romier received the position of librarian archivist of the the National Committee of French Foreign Trade Advisors. See digital acces in: < http://books.openedition.org/igpde/2217?lang=en>

37 The heated discussions on the remembrement des sols [land management and repartition], the lotissement urbain [town site] and its rationalization, was addressed and recorded in the CIAM delegates meeting of 1929, and was planned to occur in the third day of the CIAM congress. In one of the latest versions of the program, the topics to be examined have been defined with more precision in the draft program of CIAM II entitled Zweiter Internationaler Kongress fuer neues Bauen. Soziale Forderung und Technische Verwirklichung der Kleinwohnung, Meeting of the delegates in Basel 2 February 1929. gta/ETH archives

${ }^{38}$ LC married French model Yvonne Gallis in Paris on the 18th December 1930

39 Letter from LC to his mother, November 28, 1928, FLC. Apud Baudouï, R., and Dercelles. A.: Le Corbusier. Correspondance. Lettres à la famille 1926-1946, p. 194
} 
McLeod's work on Le Corbusier and the Redressement not only draw attention to the fact that Le Corbusier "was enlisted to participate on an urban study committee" headed by Romier, but also argued that the architect's two publications in the group's Bulletin in 1928 were "among Le Corbusier's most explicit espousals of technocratic doctrine", ${ }^{40}$ a clear example of attempt "to influence policy decision while maintaining [a certain] independence from politics". ${ }^{41}$ The scholar built a convincing argument for Le Corbusier's incorporation of US models of industrial productivity in his discourse, such as Taylorism, proving how significant had been the role of major voices of the Redressement for strengthening the construction of texts produced by Le Corbusier in late twenties. Furthermore, McLeod points to a shift in Le Corbusier's understanding of his social role after experiencing failures of such US models of industrial productivity at work, ${ }^{42}$ holding that Le Corbusier's critical look and judgment of these models would only take place from the thirties onwards, at a time when a general refusal of US apparatus and ideas is established amongst the several circles of French society. ${ }^{43}$

If, on one hand Le Corbusier's publications by 1930 are clear evidences of a rupture and hesitation when considering US ideals, a doubtless contribution credited to the investigation of McLeod; on the other hand equally significant here would be to recognize that Le Corbusier's writings of the mid-twenties already indicated certain resistance to the discourses and practices produced in the US and exported worldwide. One of Le Corbusier's criticisms of this period has been precisely the impact of such industrial ideologies upon the urban form of big cities, such as the settlement of skyscrapers in New York. ${ }^{44}$

The book Une maison, un palais serves here as good example. The tone in which Le Corbusier structures the narrative to defend his project of the Palais des Nations, embraces a criticism of the chaotic modern cities, exemplified with the image of New York from above. Published in 1928, the fifth book of the series of L'Esprit Nouveau Collection does not escape from the rhetoric discourse built with images and texts, which also prevailed in Le Corbusier's earlier books from the same collection. ${ }^{45}$ The discourse on the US urban design is, however, slightly different from those others of that collection. Le Corbusier places the drawing entitled "urbanisme américain" in tandem with a picture taken by himself of Versailles entitled "l'escalier de Cent Marches", and argues that the American proposals and ideals are of immeasurable consequence by not having

\footnotetext{
${ }^{40}$ McLeod, M.: “Architecture or Revolution: Taylorism, Technocracy, and Social Change”, p.142

${ }^{41}$ Ibid, p. 144

${ }^{42}$ Ibid

${ }^{43}$ Several authors have pointed out certain homogenous- or even "oversimplified"- visions of the United States built by twentieth-century French society. For example, when examining poet Blaise Cendrars' first impressions of the US, Yvette Bozon-Scalzitti defines in a few but clear words such dominant views. See: Bozon-Scalzitti, Y. "L'Amérique Invisible de Cendrars", p. 150

${ }^{44}$ Although scholars as Passanti, Von Moos and more recently Leitner have shown not only the echoes and 'influences' produced by the debates and writings on the booming construction of skyscrapers in cities as Chicago and New York on Le Corbusier's practices before the great war and the early twenties, in particular when designing the Ville Contemporaine in 1922, but also analysis on the young Le Corbusier's approach and visions of the US; an approach to Le Corbusier's discourse of late twenties, precisely in a time when the architect began to disclose tensions, contradictions and certain suspicion concerning these 'American influences', hasn't been developed in depth. See: Passanti, F. "Des gratte-ciel pour la 'ville contemporaine", pp.54-65; and Von Moos, S.: "L'Amérique". In Von Moos (Ed.) L'Esprit Nouveau. Le Corbusier et l'industrie 1920-1925, pp.190-193; Leitner, P.: "Le rêve américain de Charles-Édouard Jeanneret", report presented to the Le Corbusier foundation in 2009, which became a chapter of his doctoral dissertation on the exchanges and transformations in Paris and New York from mid-nineteenth century until the first quarter of the twentieth century.

${ }^{45}$ The books are, respectively: Vers une Architecture (1923), Urbanisme (1924), L'Art Décoratif d'Aujourd'hui (1925), and Almanach d'Architecture Moderne (1925)
} 
"the experience" and "not knowing here" [that is, Europe], and for looking at "Versailles without understanding it". 46

In fact, before the establishment of the economic crisis that was marked by the Wall Street crash in October 1929, a number of individuals familiar to Le Corbusier had been already critical to the booming US phenomena, whose writings seemed to have produced echoes on Le Corbusier's visions of the US. Amongst them, Lucien Romier rises as revealing figure in the last two years of 1920s to conjecture the complex universe in which Le Corbusier circulates and operates, and interesting to us, the multifaceted approach towards the New World.

While being a member of the executive committee of the movement Redressement Français, Romier writes between 1927 and 1929 a number of books whose research object announces a shift compared to the earlier work as scholar trained at the Ecole de Chartres to be a political historian of the XVIth century. According to his biographers, ${ }^{47}$ Romier travels to the USA, China, Japan and Central Europe; an experience that allowed the historian "to place great emphasis on the reserves of power [- economic, political and cultural] of the New World", in particular.

In fact, not only Romier's simplistic discourse on the US and the overseas, but also statements on the mores of the modern world seem to be aligned with that of Le Corbusier of the late twenties and early thirties. ${ }^{48}$ In Romier's books, it is not rare to come across flat declarations indicating the "open spirit" or the "promptness of decision making and action" within this "homme nouveau". It is indeed tempting to single out the strong correlation between the French historian and the Swiss architect's employment of particular sentences, terms and parlance in their narratives.

One noteworthy example of Romier's book to the present discussion would be Idées très simples pour les Français, which Le Corbusier possessed. ${ }^{49}$ Short and very concise in words, this publication from 1928 is associated with a conservative stance that, instead of sharing an intellectual approach, compiles a series of statements and instructions, whose aims are, following Romier's words, the finding of effective solutions to make once more France competitive with its rivals.

“(...) il faut que chaque citoyen prenne conscience du retard où nous vivons par rapport à certains peuples étrangers qui sont nos rivaux et nos concurrents, et de la direction à suivre pour regagner notre place, au premier rang. " Lucien Romier ${ }^{50}$

\footnotetext{
${ }^{46}$ Le Corbusier: Une maison, un palais, pp.16-17

${ }^{47}$ François, M.: Lucien Romier, pp.338-355

${ }^{48} \mathrm{La}$ Ville radieuse is perhaps the book whose visual and written discourse produced by Le Corbusier is the most aligned with that of Romier's ideas written in the first part of "Idées très simples pour les francçais", which is mostly devoted to attack the "malaises" of cities and their banlieues. For further analysis on Le Corbusier's discourse of mid-thirties, see McLeod's third chapter of the doctoral dissertation, in which she argued for Le Corbusier's involvement in neo-syndicalist movements, and publications that showed the architect's projects Ville Radieuse and Ferme Radieuse

${ }^{49}$ The two books found at Le Corbusier's private library are the already mentioned Idées très simples pour les Français, whose first edition was published by Le Redressement Français in 1928; and one of Romier's most popular writing L'Homme Nouveau. Esquisse des conséquences du Progrès, from 1929. The latter was dedicated by the author to Le Corbusier. Probable is, however, that Le Corbusier would be also familiar with numerous other writings of Romier, such as the book Qui sera le maître, France ou Amérique? from 1927, whose narrative -sometimes rather repetitive too - aspires to built a polemic through a comparative method between these two societies, in political-, economic- and cultural levels.

${ }^{50}$ Romier, L.: Idées très simples pour les Français, pp. 7-8
} 
Filled with assertive sentences, the speaker of the Redressement builds in three parts a rhetoric that entices readers to urge for political action after exposing one of the author's major concerns, i.e. the question of the masses and the lack of city planning in France.

"Je n'hésite pas à dire que l'aspect des banlieues françaises, quand on les compare à l'aspect des banlieues américaines ou allemandes, est une honte." Lucien Romier ${ }^{51}$

Fragments above are just a few examples of the tone that Romier develops his ideas, not only in books but also in the series of writings published between 1927 and 1929, ${ }^{52}$ which not always seems to have had positive reception amongst his peers intellectuals and academics, such as Sigfried Giedion. ${ }^{53}$ Despite Romier's inclination for conservative statements, his examination on the US industrial, political and socio-economic models often pointed to a critical position, instead of insisting on automatic reproduction of these models in other countries. Among many other uniform statements, Romier maintained in 1927 that the US society could not be defined as a "historical nation", neither a "political corpus", but rather an "economic community in its origin", deeply affecting their notions of time and history.

The fact that the resolute hegemonic activities in the US were undermined as such also found acceptance on behalf of Le Corbuiser. Likewise Romier's words, Le Corbusier argues in Une maison, un palais for the lack of experience and historical dimension amongst les Américains. ${ }^{54}$ Le rêve américain, as conceived by the young Le Corbusier before and just after WWI, when building first notions and plans of urban space in particular, appears to be thus challenged after the second quarter of the twentieth century. ${ }^{55}$ It would be precisely in those years of exchanges with Romier, that Le Corbusier establishes a redefinition of his understanding of the New World. Furthermore, as I will show in the following, it would be notably with Cendrars, that Le Corbusier begins to seriously pay attention to 'other' Americas, this time the one located under the Equator.

\section{New Eyes in the New World: the Southern part of the Americas in Le Corbusier's Agenda}

"Cher Ami. Merci de votre Almanach E.N. que je trouve en rentrant d'Amérique (...) ATTENTION: je vous signale que le gouvernement Brésilien veut demander aux Chambres les crédits nécessaires pour la construction de la Capitale Fédérale prévue dans la Constitution (...) 'une ville d'un million d'âmes: PLANALTINA.” Blaise Cendrars ${ }^{56}$

\footnotetext{
${ }^{51}$ Ibid. pp. 29

${ }^{52}$ Concerning Romier's analysis on the US, we shall mention a series of texts published in Revue des deux mondes: "Vues sur les États-Unis. I La civilisation de masse" (September 1927), "Vues sur les États-Unis. IL Les moeurs" (September 1927), "Sur la frontière de deux Amériques" (November 1927), "Sur l'impérialisme financier" (July 1928). Some of these texts would also appear in form of chapters of the polemic book "Qui sera le Maître: Europe ou Amérique?" from 1927

${ }^{53}$ In a letter to Karl Moser, Giedion is very critical to Romier and to his book Qui sera le maître: Europe ou Amérique? (1927), attesting that Romier was a "clever and reactionary" type and his book rather "primitive". Letter from Giedion to Moser on March 14 1929, gta/ETH archives. I would like to thank Daniel Weiss for calling my attention to this letter, and Filine Wagner for the precious help in understanding Giedion's hand writing

${ }^{54}$ Here clearly referred to the US residents only

${ }^{55}$ Not just shedding light upon names from Le Corbusier's circles, I have attempted to introduce an intersection between the architect's writings and those produced by individuals, whose affinity and affection had been built, particularly in late twenties, in order to point to an early shift in Le Corbusier's discourse in consideration of his preconceptions of the Americas.

${ }^{56}$ Post Card from Cendrars (BC) to LC, 13 July 1926, FLC
} 
Planaltina is "the city of one million souls" and a "virgin area still". The words from Blaise Cendrars (18871961) to Charles-Edouard Jeanneret that reveals the construction of a new city in Brazil are full of excitement and joy. Cendrars' words attempt to call Le Corbusier attention since the Planaltina project is not any ordinary city project to be built in the overseas. It is in this land, apparently far away from the architect's horizon, that the dream of a new Federal Capital, as "provided in the Constitution" Cendrars notes, is about to take place.

The project to transfer the capital to the interior of Brazil, initially proposed by Jose Bonifacio de Andrada e Silva in 1823, one year after the Brazilian Independence from Portugal, was recovered several times through the nineteenth and the early twentieth century. ${ }^{57}$ In the early 1920 s, the project for the new capital once again became part of the political agenda in Brazil. On 7 September 1922, the date of the 100th anniversary of Brazilian independence from Portugal, the first stone was placed, giving evidence that the dream of the future capital was about to become a reality. Soon this fact and news would not go unnoticed for Cendrars, whose eyes are keen to the American continent, gaining new strength and dimension in particular after 1923, the year when the poet meets the artistic and political circle from Brazil in Paris. The frisson of 'making Planaltina' is not only evoked in Cendrars' letters, but also in other documents, such as on the cover of the book novel L'OR from 1926, offered by the poet to the architect. To Jeanneret, Cendrars writes: "ce bouquin de L'Or en lui souhaitant d'engager en faisant Planaltina". ${ }^{58}$

"En effet, le rêve de "Planaltina" me trotte en tête", Le Corbusier declares to Paulo Prado, the Brazilian entrepreneur who sponsors Cendrars' trips to this country, and who would also promote Le Corbusier's trip in the second semester of $1929 .^{59}$

Written in July 1929, that is, three years after Cendrars' first mention of the Brazilian plans for a new capital, the letter leaves no doubt about Le Corbusier's great interest in new lands such as Brazil. Both architect and poet became in fact obsessive about the idea of making Planaltina. It was indeed an extraordinary chance to construct new ideas in the new world. Despite their engagements, the idea finally did not accomplish concrete results as expected. However, it unfolded new avenues and interests to Le Corbusier, whose impacts would be visible in his discourse right after the stay in Brazil.

Through the surviving letters written to Le Corbusier during the twenties, Cendrars' words are filled with excitement about Brazil and the new possibilities that it may provide to both poet and architect. ${ }^{60}$ On 26 July 1926, Cendrars once again encourages his friend to learn about the projects that are taking place on the other side of the Atlantic. As Margareth da Silva Pereira and Alexandre Eulalio have already shown, it would be however only in 1929, at a time when singular opportunities to build in America (north and south) present themselves to Le Corbusier, that the architect would begin to seriously consider the assistance of his friend, the poet. The first

\footnotetext{
${ }^{57}$ Petropole or Brasilia, these were the two possible suggestions by De Andrada e Silva to name the new capital. In 1920s the name of Planaltina is also suggested within the debates, but Brasilia ended up to be the definitive name, being executed during Juscelino Kubitschek's governance (1956-1961), more than a centenary after De Andrada's project. For a detailed reading on De Andradas' project of the Federal Capital read De Andrada e Silva, J. B.: O Patriarcha da Independência; Magalhães, M.: "Jose Bonifacio's Brasilia in Between Brazil: Multiple Territorial Scales of Planning Collective Life"

${ }^{58}$ The book is part of the Le Corbusier's files, FLC

${ }^{59}$ Letter from LC to Paulo Prado on 28 July 1929, FLC

${ }^{60}$ Although the relationship between Cendrars and Le Corbusier have not been yet an object of study, these two letters mentioned in the present chapter have been already published and mentioned by scholars who have studied the relationship between Le Corbusier and Brazilians. See, Da Silva Pereira, M.: Le Corbusier e o Brasil
} 
attempt of a trip to the Americas, in fact, considered passing through the cities of Rio de Janeiro, São Paulo, Montevideo, Buenos Aires, and Oklahoma city, too. ${ }^{61}$

"C'est décidé, j’irai à Buenos-Ayres (...) Alors, votre amitié me managerait-elle au pays du café? c-à-d pourriez-vous en écrire utilement là-bas, obtenir un engagement, + des conditions (je veux dire: la peine du dérangement!) (...) Pour Buenos-Ayres, on m'attend en août.septembre voyage: Pour mes aises, dites-moi donc quel paquebot, quelle ligne et en deux mots, comment on peut s'ébaudir sur la maison flottante. Voilà! Et merci de tout cour (un type de Oklahoma City USA, nous demande des plans de maisons de série et demande "pour quelle somme on pourrait négocier avec nous"? Dites-moi donc combien nous valons là-bas. Amitiés Ch.E. Jeanneret" 62

In response to Le Corbusier's requests, Cendrars promptly confirms he would contact São Paulo to organize conferences for Le Corbusier in São Paulo and Rio, so he could be introduced to the major of Rio de Janeiro, who has plans to reconstruct the city. ${ }^{63}$ In fact, as well as extending Le Corbusier's networking overseas, the relationship between these two protagonists goes far beyond shared social circles. Cendrars seems to have affected and transformed Le Corbusier's impressions of the Americas, and particularly of Brazil.

Through Cendrars' poems, novels, letters and most probably dinners and encounters in Paris - this would probably explain the reason why so few letters can be found - Cendrars introduced multiple Brazils to Le Corbusier, whose narratives follow neither linear nor logical structures and orders. As a friend, traveler and, of course, as a poet too, Cendrars would have contributed strongly to shaping Le Corbusier's ideas of Brazil, a country which turned to be pivotal in the architect's agenda for the Americas. The mid-twenties would be critical for both figures' encounters. Issues related to the new world, and to Brazil in particular, aren't the only ones that emerged. However, it's been precisely this theme that would become the pivot for their exchange and intellectual shifts. $^{64}$

\section{Blaise Cendrars: la main amie or the Bridge between two Worlds}

On 28 May 1923 Cendrars welcomes two new visitors to his place, Brazilian writer Oswald de Andrade (18901954) and painter Tarsila do Amaral (1886-1973), two key figures, who co-organized the first Modern Art Week in Brazil in $1922 .^{65}$ The meeting seems to have been a success as not only due to a close affinity that grew between them in very short time, but also their work produced henceforth indicates a mutual exchange of influential ideas, and a considerable shift in approach, particularly for Cendrars.

The Parisian stay of the couple Tarsila and Oswald in the early twenties indeed agitates encounters between Cendrars and several other intellectuals -Le Corbusier included- whose engagement with issues related to

\footnotetext{
${ }^{61}$ Notes of LC in his agenda of 1929, FLC

${ }^{62}$ Letter from LC to BC on 7 May 1929, FLC

${ }^{63}$ Letter from BC to LC from 1929, FLC

${ }^{64}$ Le Corbusier Foundation (FLC) and Blaise Cendrars' files at the Swiss Literary Archives in Bern (ALS) offer relevant material that allows us to trace this exchange to a greater extent

${ }^{65}$ The First Art Week hosted a group of participants that advocated for the introduction of a 'new attitude' among the Brazilian Artistic field. This group fought to establish their own understanding of a Brazilian modernity, at home and abroad, as in the case of Oswald Andrade's lecture L'effort intellectuel du Brésil contemporain in May 1923 at Sorbonne, the same institution that housed Le Corbusier's lectures a year before. See, Amaral, A.: Blaise Cendrars no Brasil e os modernistas: Tarsila: sua obra e seu tempo; Rossetti Batista, M.: Anita Malfatti no tempo e no espaço: biografia e estudo da obra; Eulalio, A.: A aventura brasileira de Blaise Cendrars
} 
the modern world and its boundaries, are clearly presented and shared. After the encounter in May, it would not take long for Cendrars to find himself in close contact with Brazilian artistic and political circles based in Paris. The dinner organized in October of the same year by Brazil's Ambassador to France, Luis Martins de Souza Dantas, ${ }^{66}$ which furthermore gathers familiar figures to Cendrars such as Fernand Léger, Darius Milhaud, among others; ${ }^{67}$ has been one of many events that Cendrars attended and at which he felt great empathy with the ideas and revelations that evolved from it.

Through Oswald, Cendrars also meets Paulo Prado (1849-1943) in Paris, a rich and an influential sponsor of modern art in Brazil, who would become one of the poet's dearest friends and paid for Cendrars and Le Corbusier's trips to Brazil. During Prado's long stays in Paris in the mid-twenties, he often met Cendrars and Léger. In 1928, the presence of Le Corbusier in those meetings was sporadic. ${ }^{68}$ Despite not being evident in the survival archival material, but considering the architect's great interest in establishing connections in Brazil, it seems reasonable to assume that Le Corbusier was familiar with social and cultural events organized by the Brazilians who were part of the same circles of Cendrars and Léger, such as Tarsila do Amaral's second individual exhibition in Galerie Percier from May until June 1928, as well as the critic's reviews that had been published. Amongst the paintings exhibited, Antropofagia.

As stated by a number of scholars, Cendrars and Le Corbusier' rapprochement to the Brazilians wouldn't be thus a coincidence, as both sides of the interest in the exchange were present. ${ }^{69}$ From the Brazilians' perspective, the rapport with figures within which efforts to redefine artistic practices in accordance with their time proves fundamental in order to legitimize their discourses in counterpoint to the cultural traditionalism in the country. Yet deciphered by the positions of Cendrars and Le Corbusier's standpoint, Brazil begins to be perceived as a place open to new ideas, whose intellectual autonomy and vision of modernity was not subordinated to any style or "ism", to borrow Cendrars' terms.

\section{The Americas of Cendrars become the Americas of Le Corbusier}

During the twenties in particular, Brazil would then become a great theme to Cendrars. He would not only write on Brazil and together with Brazilians, but also write several of his novels during his stays in the country. Cendrars traveled three times to Brazil, trips lasting usually two to three months. In this travels, the poet discovers São Paulo by car; visits the historical centers of cities in Minas Gerais for example; where there is a

\footnotetext{
${ }^{66}$ Souza Dantas (1876-1954) served as Brazilian ambassador in France for more than twenty years, from 1922 until 1944, that is, during the Vichy government too. He was not only an important figure who embraced cultural exchanges between Brazil and France, as described in this work, but he also gained international notoriety by granting visas for entry into Brazil for hundreds of people persecuted by the Nazis during the WWII

${ }^{67}$ According to a paper published in the Brazilian Review Ariel by Brazilian writer Sergio Milliet, who was presented in the ambassador's dinner, the list of guests who attended the event were: Léger, Cendrars, Milhaud, Andre Lhote, Jules Romains, Jean Giraudoux and Jules Supervielle, and among Brazilians, Tarsila, Oswald de Andrade, Victor Brecheret, Vicente do Rêgo Monteiro and Pinheiro Júnio. Apud A. Amaral, Tarsila. Sua obra e seu tempo, p. 90

${ }^{68}$ Evidences of these meetings with Leger and Prado are found in Le Corbusier's agenda of 1928 (from 02.28 till 08.1928) and correspondence with family, such as the letter to his mother on July 12 1928, FLC

${ }^{69}$ George, W. Tarsila et l'anthropophagie, La Presse, Paris, 5 July 1928. The English version of the fragment published above originally appeared in: Greet, M. "Devouring Surrealism: Tarsila do Amaral's Abaporu”, p.9
} 
high concentration of the most notable Brazilian baroque churches, as well as, buildings and squares; while, once in Rio, he participates in carnival parades, and, just like Le Corbusier in 1929, he joins bohemian rodas de samba (samba dances and social circles) and wanders around in the carioca Favella. Cendrars is profoundly affected by these trips and Brazil becomes a very strong source of inspiration for his poems and other activities for many years to come. The Swiss-French author of la prose du Transsibérien would be engaged to produce not only books based on "Brazilian heroes" and stories such as the baroque artist Aleijadinho, but also film project on Brazil.

\section{"Belle soirée}

Le soir tombe sur la côte américaine

Pas un poisson pas un oiseau

Une chaîne continue de montagnes uniformes toutes recouvertes d'une végétation luxuriante

La mer est unie

Le ciel aussi

Je pense aux deux amis que je me suis fait à bord et qui viennent de me quitter à Rio

(...)

Je n'ai jamais autant ri depuis dix ans et ri durant vingt jours j'étais malade de rire et ai augmenté de six kilos Au revoir mes bons amis à bientôt nous nous retrouverons à bord en rentrant en France ou un autre jour à Paris ou à Bruxelles ou ailleurs dans un train qui franchira les Andes ou à bord de l'Emperess qui cinglera vers l'Australie nous aurons toujours le même barman car le monde est bien petit pour d'aussi gais compagnons A bientôt à bientôt"

Blaise Cendrars, Feuilles de Route, 1924

Most of Cendrars' books within Le Corbusier's files - which were published in the twenties (and identified that which Le Corbusier had received or acquired at this same time) - are embedded with stories of Brazil, Cendrars' own experiences in the tropics, and many other experiences the poet had while traveling. Some of them were even written during his stays in Brazilian lands, such as Moravagine (1926) or even Dan Yack (1929). Despite not being found in the architect's library, Cendrars published two texts in the 1920's that had very good chances to be familiar to Le Corbusier. These are the poem Une Nuit dans la Forêt (1929), as well as the publication Feuilles de Route (1924) containing illustrations by Tarsila do Amaral.

"Depuis, j'ai entendu de lui des histoires américaines, des histoires du Brésil, des histoires de serpents de quinze mètres de long, de crocodiles, de fleurs dangereuses, etc... Cendrars n'a jamais manqué d'idées. Il avait le don de la matérialité des faits émotionnels" Le Corbusier ${ }^{70}$

In fact, the poet's representations of the Tropics and the Americas were rather distinct from the imaginary the European artists' had built over the 19th and beginning of the 20th century. Yet, the cities as Rio and São Paulo no longer appeared to be far from the French cities that he was familiar with such as Paris, Nice or London. On the contrary, despite the fact that it happens to be settled thousands of miles away from Europe, São Paulo appeared to be less distant than 'homeland' La Chaux-de-Fonds, for instance.

\footnotetext{
${ }^{70}$ Le Corbusier. "Salut à Blaise Cendrars : Toi, au moins, tu crois à ce que tu fais", FLC
} 
"Saint-Paul

J'adore cette ville

Saint-Paul est selon mon cour

Ici nulle tradition

Aucun préjugé

Ni ancien ni moderne

Seuls comptent cet appétit furieux cette confiance absolue cet optimisme cette audace ce travail ce labeur cette spéculation qui font construire dix maisons par heure de tous styles ridicules grotesques beaux grands petits nord sus égyptien yankee cubiste

Sans autre préoccupation que de suivre les statistiques prévoir l'avenir le confort l'utilité la plus value et d'attirer une grosse immigration

Tous les pays

Tous les peuples

J'aime ça

Les deux trois vieilles maisons portugaises qui restent sont de faiences bleues"

Blaise Cendrars, Feuilles de Route, $1924^{71}$

Through Cendrars' words, ideal denoting Brazil as an 'exotic', 'primitive' and 'wild' land is demoted and replaced by the notions of Brazil as plural, complex and urban; as well as in a constant process of change. As Claude Leroy states, Cendrars "inventoried"72 and brought value to the most current products which were "born and which died daily': the automobile, the train, the airplane, the street etc. The attention he gave to describe, for instance, the car noises of São Paulo city or even the different sounds and languages of its people were evidences of how significant such elements and experiences became for Cendrars.

\section{"SÂO PAULO}

Enfin voici des usines une banlieue un gentil petit tramway

Des conduites électriques

Une rue populeuse avec des gens qui vont faire leurs emplettes du soir

Un gazomètre

Enfin on entre en garde

Saint-Paul

Je crois être en gare de Nice

Ou débarquer à Charring-Cross à Londres

Je trouve tous mes amis

Bonjour

C'est moi"

Blaise Cendrars, Feuilles de Route, $1924^{73}$

The Americas for the poet wouldn't be detached from the notions of 'freedom', 'modernity', and, neither, of from that of 'cannibalism' too. Cannibalism, as defined by Oswald de Andrade, the author of the

\footnotetext{
${ }^{71}$ The poem São Paulo was also published in the catalogue of Tarsila do Amaral's exhibition in Galerie Percier, Paris 1926

${ }^{72}$ See, preface by Claude Leroy in: Cendrars, B. Poésies completes: avec 41 poèmes inédits

${ }^{73}$ See note 71
} 
Anthropophagic manifest (1928), as being the 'inescapable' but a 'most lucid' attitude towards their present time. Such a term embedded with meanings of Montaigne and yet re-appropriated by the "youth of São Paulo", 74 borrowing Le Corbusier's words, not only seduces both poet and architect but also seems to become quickly incorporated in their vocabulary - written and visual. Précisions (1930) and the first sketches made in Brazil, which were published in Le Corbusier's oeuvres complètes (1934), would be the first and most evident publicized signs of the architect's 'appropriation' of such a vocabulary practiced by this group from Brazil. ${ }^{75}$

“Ces pays, Argentine - vieille Castille, - Brésil - vieux Portugal -, sont arrivés à l'heure où ils veulent dessiner leur histoire. L'histoire des peuples n'est jamais que l'expression d'un idéal contemporain, une fabrication spirituelle qui est comme une doctrine, une description de soi-même, une définition de soi. L'histoire n'est pas, on la façonne. (...) on devient Américain en Amérique bien qu'on soit émigrant de partout. Les jeunes de SaintPaul m'ont exposé leur thèse: nous sommes des "Anthropophages"”. Le Corbusier. Prologue Américain, 1929

These Americas re-presented by Cendrars would be the one that most affected Le Corbusier in those years, precisely when the architect would begin to manifest a more critical position towards the hegemonic political and economic discourses produced above the Equator. These Americas: not that of the virile economy where technocracy exercised its power, yet that of other complexities and possibilities instead. One that is associated with the idea of an utopia, with a certain romanticism and naivety too, as it does not intend to challenge the oppressive Eurocentric discourse built over centuries, but that is connected to a notion of modernity shared by a group of individuals, who will leave him room for creation and interlocution.

\section{Acknowledgments}

I would like to acknowledge my appreciation to the staff of the Fondation Le Corbusier in Paris, Michel Richard, Arnaud Dercelles and Bénédicte Gandini, in particular; of the Fonds Blaise Cendrars at the Swiss Literary Archives in Bern (ALS); and of the gta Archives in Zurich. I am grateful to Marie-Thérèse Lathion from the ALS and Prof. Claude Leroy for their generosity in guiding my discovery of Cendrars' files. Also I would like to thank Daniel Weiss, Filine Wagner from the gta Archives and my colleague Andreas Kalpakci, for the open discussions on Giedion, Voisin and Romier. This paper has benefited from discussions at the doctoral seminar organized by Prof. Tim Benton on Le Corbusier at EPFL in Lausanne, and the doctoral colloquia in Architectural Theory organized by Professors Ákos Moravánszky and Laurent Stalder at the ETH Zurich. Prof. Margareth da Silva Pereira, and my colleagues Mário Magalhães and Priscilla Peixoto, whose conversations and writings have been crucial to the formulation of many of the paper's ideas. Finally, Jennifer Robin Caras, who has generously revised and corrected the English manuscript.

\footnotetext{
${ }^{74}$ Le Corbusier, Précisions sur un état présent de l'architecture et de l'urbanisme, Paris: Editions Vincent, Fréal, 1960, p.17

${ }^{75}$ Le Corbusier's drawings of the urban design for the city of Rio de Janeiro, for example - quickly sketched in his private carnets while flying over the city - was immediately transformed into public discourse during his lecture in the same city. In other words, it was while he was traveling through Brazil that Le Corbusier publicized his narratives as a tourist and as an architect in parallel - narratives based on his experiences in loco. This combination of traveller, tourist, architect, urban designer and lecturer is singular in comparison to his previous voyages. In fact, the voyages Le Corbusier carried out in the end of the twenties and beginning of the thirties - in particular to the U.R.S.S., Brazil, Argentina and Algeria - produced a relevant impact on his architectural and written production. Cohen's meticulous investigation on Le Corbusier's trips to the U.R.S.S. calls attention to the architect's expectations before traveling; as well as the confrontation of such expectations once on site and the reception of his ideas among the political and architectural milieu. Nevertheless, it would be in the Brazilian voyage that Le Corbusier would attain the maturity in his discourse and, will establish the year of 1929 as the moment of rupture in his work and concerns regarding Architecture. See, Le Corbusier, 'Oeuvre Complète 1929-1934'
} 


\section{Bibliography/references}

AMARAL, A. Blaise Cendrars no Brasil e os modernistas. São Paulo: Martins, 1970

. Tarsila. Sua obra e seu tempo. São Paulo: Perspectiva/Edusp, 1975

BACON, M. Le Corbusier in America. Travels in the Land of the Timid. Cambridge; London : The MIT Press, 2001

Le Corbusier et l'Amérique, première rencontre. In COHEN, J-L and DAMISCH, H. (Ed.) Américanisme et Modernité. L'idéal américain dans l'architecture. Paris : EHESS ; Flammarion, 1993, p. 191-207

BANHAM, R. Avant Garde und Industrie by Stanislaus von Moos. Journal of the Society of Architectural Historians, October 1984, vol. 4, no. 3, p. 277

BAUDOUÏ, R., DERCELlES, A. Le Corbusier. Correspondance. Lettres à la famille 1926-1946. Tome II. Gollion: Infolio, 2013

BENTON. T. La réponse de Le Corbusier à la loi Loucheur. In LUCAN, J. (Ed.) Le Corbusier: une encyclopédie. Paris: Centre Georges Pompidou, 1987. p. 238-239

__. Le Corbusier conférencier. Paris: Moniteur, 2007

BOZDOGAN, S. Journey to the East: Ways of Looking at the Orient and the Question of Representation. Journal of Architectural Education, Summer 1988, vol. 41, no. 4, p. 38-45

BOZON-SCALZITTI, Y. L'Amérique Invisible de Cendrars. In CHEFDOR, M. (Ed.) Blaise Cendrars 2. Cendrars et l'Amérique. Paris: Lettres Modernes, 1989, p. 145-176

CENDRARS, B. La Fin du monde filme par l'ange N.D. Paris: Ed. De la Sirène, 1919

Feuilles de Route. Paris : Au Sans Pareil, 1924

. L’Eubage. Aux Antipodes de l'unité. Paris: Au Sans Pareil, 1926

. Une Nuit dans la Forêt. Paris: Denoel 1964

Poésies completes: avec 41 poèmes inédits, Claude Leroy (ed.), Paris: Denoël, 2001

COHEN, J-L. Le Corbusier et la mystique de l'URSS. Théories et projets pour Moscou 1928-1936. Paris: Pierre Mardaga Editeur, 1987

. Le Corbusier : La planète comme chantier. Paris : Textuel, 2005

(Ed.) Le Corbusier: An Atlas of Modern Landscapes. New York: The Museum of Modern Art, 2013

COHEN, J-L., DAMISCH, H. (Ed.) Américanisme et Modernité. L'idéal américain dans l'architecture. Paris: EHESS; Flammarion, 1993

DA SILVA PEREIRA, M. et al. Le Corbusier e o Brasil. São Paulo: Tessela/Projeto Editora, 1987

EULALIO, A.; CALIL, A. A aventura brasileira de Blaise Cendrars, São Paulo: Edusp, 2001

FRANCLIEU, F. et al. Le Corbusier Sketchbooks. Vol 1, 1914-1948, London: Thames and Hudson, 1981

FRANÇOIS, M. Lucien Romier. Bibliothèque de l'école de chartres. 1944, vol. 105, p.338-355

GIEDION, S. Building in France, Building in Iron, Building in Ferroconcrete. Santa Monica: The Getty Center for the History of Art and the Humanities, 1995

GREET, M. Devouring Surrealism: Tarsila do Amaral's Abaporu. Papers of Surrealism, Spring 2015, Issue 11, p.1-39

KUISER, F. Ernest Mercier: French Technocrat. Berkeley - Los Angeles: University of California Press, 1967

LE CORBUSIER. Vers une architecture. Paris: Editions G. Crès et Cie, 1923 
. Urbanisme. Paris : Editions G. Crès et Cie. Paris, 1925

. Une maison, un palais. Paris : Editions G. Crès et Cie à Paris, 1928

$\overline{1930}$

Précisions sur un état présent de l'architecture et de l'urbanisme. Paris : Editions G. Crès et Cie à Paris,

La Ville radieuse. Paris : Editions Vincent, Fréal \& C, 1935

. Oeuvre complète 1929-1934, tome 1, publié par W. Boesiger, Girsberger. Zurich: Artémis 1957

. Salut à Blaise Cendrars : Toi, au moins, tu crois à ce que tu fais. La Gazette de Lausanne, March 14, 1960

. Le parcellement du sol des villes, in Rationelle Bebauungsweisen. Ergebnisse des 3. Internationalen Kongresses für Neues Bauen. Nendeln: Kraus, 1979. Copyright 1931 by Verlag Englert \& Schlosser, Frankfurt am Main. p.48-57

Le Corbusier et le livre. Les livres de Le Corbusier dans leurs éditions originelles. Ouvrage publié à l'occasion des expositions produites par le Collegi oficial d'Arquitectes de Catalunya, Barcelona, April 2005

LEITNER, P. Entre Paris et New York. Dynamiques d'échange pour transformer la métropole 1858-1926. Supervisor: Jean-Louis Cohen. Doctoral Dissertation. Université Paris VIII, Vincennes - Saint-Denis, 2009

"Le rêve américain de Charles-Édouard Jeanneret". Report presented to the Le Corbusier Foundation , Paris, 2009

LUCAN, J. (Ed.) Le Corbusier: Une Encyclopédie. Paris : George Pompidou : 1987

MAGALHAES, M. Jose Bonifacio's Brasilia in Between Brazil: Multiple Territorial Scales of Planning Collective Life. Annals of the16th International Planning History Society Conference, St. Augustine (USA), July 2014

MCLEOD, M. Architecture or Revolution: Taylorism, Technocracy, and Social Change. Art Journal, Summer 1983, vol.43, no.2, p.132-147

Urbanism and Utopia: Le Corbusier from regional syndicalism to Vichy. Supervisor: Kenneth Frampton. Doctoral Dissertation, Princeton University, Princeton N.J, 1985

Le rêve transi de Le Corbusier: l'Amérique 'catastrophe féerique'. In COHEN, J-L and DAMISCH, H. (Ed.) Américanisme et Modernité. L'idéal américain dans l'architecture. Paris : EHESS; Flammarion, 1993, p.209-228

PASSANTI, F. Des gratte-ciel pour la "ville contemporaine". In VON MOOS, S. (Ed.) L'Esprit Nouveau. Le Corbusier et l'industrie 1920-1925. Strasbourg: Les Musées de la Ville de Strasbourg, 1987, p.54-65

Le Corbusier et le gratte-ciel, aux origines du Plan Voisin. In COHEN, J-L and DAMISCH, H. (Ed.) Américanisme et Modernité. L'idéal américain dans l'architecture. Paris : EHESS; Flammarion, 1993, p.171190

The Vernacular, Modernism and Le Corbusier. Journal of the Society of Architectural Historians, December 1997, vol. 56, no 4, p.438-451

RABINOW, P. French Modern. Norms and Forms of the Social Environment. Cambridge (Massachusetts): The MIT Press, 1989

ROMIER, L. Qui sera le maître, France ou Amérique?. Paris: Hachette, 1927

. Idées très simples pour les Français, Paris: Simon KRA, 1928

. L'Homme Nouveau. Esquisse des conséquences du Progrès, Paris: Hachette, 1929

ROSSETTI BATISTA, M. Anita Malfatti: no tempo e no espaço. São Paulo: Editora 34, 2006

SHAW, M. Promoting an Urban Vision: Le Corbusier and the Plan Voisin. Supervisor: Francesco Passanti. Master's thesis. MIT, Cambridge, Massachusetts, 1991 
VON MOOS, S. Le Corbusier: Elements of a synthesis, Rotterdam: 010 Publishers, 2009. 1st ed. Published in German Le Corbusier: Elemente einer Synthese, by Huber (1968)

Urbanism and Transcultural exchanges, 1910-1935: A Survey. In ALLEN BROOKS, H. (Ed.) Le Corbusier. Princeton: Princeton University Press, 1987, p.219-232

VON MOOS, S. et al. L'Esprit Nouveau. Le Corbusier und die Industrie, 1920-1925. Berlin: Ernst \& Sohn, 1987

VON MOOS, S., RÜEGG, A. (Ed.) Le Corbusier Before Le Corbusier. New Haven; London: Yale University Press, 2002 